\title{
Restricted Liberty, Parental Choice and Homeschooling
}

\section{MICHAEL S. MERRY AND SJOERD KARSTEN}

\begin{abstract}
In this paper the authors carefully study the problem of liberty as it applies to school choice, and whether there ought to be restricted liberty in the case of homeschooling. They examine three prominent concerns that might be brought against homeschooling, viz., that it aggravates social inequality, worsens societal conflict and works against the best interests of children. To examine the tensions that occur between parental liberty, children's interests, and state oversight, the authors consider the case of homeschooling in the Dutch context.
\end{abstract}

A number of political virtues are prized in all liberal democratic societies; these include liberty, toleration and equality. Though the value of each may be weighted differently according to time, place and circumstance, liberty is fundamental. Liberty is the means by which persons are able to exercise their moral agency absent of coercion, and without liberty all talk of toleration and equality collapses. The best way to facilitate liberty is to allow persons to pursue their interests according to their own principled beliefs so long as they do not unduly interfere with, or limit, the liberty of others. With liberty comes the right to make decisions about oneself and one's possessions without unwarranted interference. Therefore, apart from its legitimate paternalist forms, coercion is wrong except where it is necessary to restrain the abuse of liberty.

The state is called upon to promote justice by legitimately arranging the liberties of persons in the social and political sphere. It does this in at least two ways. First, it will subsidise or provide services, such as public transportation, health care, housing and education, without which many citizens would be less free to take up meaningful pursuits. So with respect to liberty, the state's role is that of enabler. Yet paradoxically the state also enables by restricting human liberty. For instance, states organise and regulate freedoms, say through progressive taxation or anti-trust laws, so that persons (or corporations) with more resources are less able to exploit those without them. Yet even when just states restrict liberty, such actions are only justifiable when it can be shown that doing so promotes other goods, such as greater equality or social order.

When it comes to regulating or ordering liberty, liberal states are generally more democratic agencies of just distribution, by which citizens 
may avail themselves of valuable social goods. Thus, with respect to education, the liberal state will also use its authority and overview to promote basic opportunities of all children irrespective of background or wealth. These opportunities are intended to promote basic competencies such as literacy, but also from civic capacities concerning the way the political institutions function and the skills needed to influence the political process.

Yet the authority of the state, even in the freest and most equitable societies, has never been uncontroversial. In all liberal democracies there remain hard tensions between personal liberty and equity, pluralism and democratic access, and among different conceptions of what constitutes a good life. These tensions are perhaps especially visible in the educational sphere. Indeed, in all liberal democracies the freedom to choose the type of education one wishes his or her child to have-provided it is both available and affordable - is an assumed parental right. Where basic educational opportunities exist, and rudimentary political freedoms are secured, paternalist rights are supported by the fact that parents generally assume primary responsibility for raising their own child, even if that responsibility entails - for a majority of parents-the habit of sending their child to the nearest public school. So parents generally enjoy considerable freedom in deciding the type of upbringing and education their children receive. What remains to be seen is whether the parental appeal to personal liberty in educating one's child at home potentially conflicts with the aim of promoting the interests of children and whether the state has a role to play in seeing that those interests are secured.

In order to give these tensions a sharper focus, we will examine the case of homeschooling. Homeschooling is an illustrative example because parents who homeschool question the conventional wisdom that going to school makes a child more free. Further, homeschooling represents the ultimate expression of parental liberty (and authority) over a child's education: by effectively removing one's children from school, parents express their educational preferences in ways that appear to directly challenge the paternalistic role that states typically assume. Further, in many countries, homeschooling is carried out with very little direct oversight (Glenn and de Groof, 2002); accordingly its growth is generally viewed with consternation by the wider public. Meanwhile, homeschoolers have fought, and continue to fight, difficult battles in the courts in order to secure their parental liberty to educate their children as they desire (Isenburg, 2007; Somerville, 2005). Yet if states assume an important guardian role both in the provision and supervision of education, should parental liberty be restricted in order to secure important personal and social goods, and on what grounds might that be established?

To assess the challenges that homeschooling poses (and faces) as a marginal, and perhaps uncertain, alternative to educational options directly under government supervision, we will briefly consider the situation in the Netherlands. The Dutch case is particularly illuminating for several reasons, not least of which is that homeschooling, while not 
illegal, is certainly marginalised. Indeed, the Dutch continue to view homeschooling as both unnecessary and undesirable. Second, in the Netherlands both freedom of education and parental liberty are uncontested constitutional rights when choosing an education for one's child, though all schools-public and private-are subject to state oversight. Third, the Netherlands has an extremely diverse school choice system-incorporating a variety of school types - in which it is at least theoretically if not practically feasible to attend any school one wishes to attend without prohibitive costs involved. Fourth, while being generous in its support of educational diversity, the Dutch state sets arbitrary limits on the types of education available to parents. Consequently, homeschooling, for the moment, represents a direct challenge to the way freedom of education is usually interpreted and applied in the Netherlands. Therefore, the Dutch situation is a suitable 'test case' for it exemplifies many tensions one associates with restricted liberty and parental choice.

We will proceed as follows. In the first section, we examine the place of personal liberty as a good, and the state's role in facilitating and protecting it. We show that while parental freedom is not boundless, the importance of robust pluralism for liberal societies, perhaps especially in the educational sphere, warrants its protection. We also highlight the role both parents and the state play in protecting children's interests. We then sketch the outlines of a citizenship argument and an autonomy argument, foreshadowing later discussion.

In the second section, we examine the reasons why homeschooling in the Netherlands remains a difficult path to pursue, and whether these difficulties are consistent with its own constitutional guarantees of freedom of educational choice. We assess the features of the Dutch educational model, one in which there is considerable pluralism and parental liberty, yet one that simultaneously restricts how that liberty is applied. We ask whether the restriction of liberty in the case of homeschooling is tenable.

In the third section we return to the worries over citizenship and autonomy, and evaluate the strengths of these arguments vis-à-vis homeschooling. We specifically evaluate the following claims brought against homeschooling: (1) that it aggravates social inequality; (2) that it increases societal conflict, and finally (3) that homeschooling interferes with the wellbeing and interests of children. We argue that parents are generally better placed to attend to the needs of their own children, but that parental liberty - in education as in other matters-in some cases may require restriction so that the best interests of children are served. For this some type of oversight is required but in order to justify the restriction of parental liberty the state must attend to the specifics of individual cases.

\section{LIBERTY, THE FAMILY AND THE STATE}

Perhaps with the exception of self-contained anarchist communities (e.g. kibbutzim, free and modern school movements) arguably equipped to 
govern themselves, a minimalist state is typically necessary, if for no other purpose than to arrange the liberties of persons in the social and political sphere. Put another way, the state serves the important purpose of protecting the rights of citizens to exercise their natural liberties as they see fit provided the liberties of others are not violated. Indeed, laws governing public health and safety may be enacted for the legitimate purpose of restricting human liberty and promoting justice. This constitutes the state's legitimate paternalist role.

Most persons recognise that some oversight is required as it pertains to what persons do with their liberty. For example, traffic and weapon laws legitimately restrict what persons can do with their liberty in order to secure relative order and security. Even principled libertarians, who place considerable stock in their liberty to dispose of their property as they choose, would nevertheless recognise important 'side constraints' (see Nozick, 1974). These constraints describe things we are not permitted to do if the result is to recklessly disregard the interests of others. Hence even libertarians are prepared to admit some (coercive) state interference for the purpose of protecting liberty rights.

Yet more than merely protecting or regulating liberty, states also play an important role in facilitating it. For example, states typically assume the responsibility for providing and regulating the education of children. States ensure legal entitlement of all children to a minimally adequate education but also have among their aims to promote literacy and numeracy skills sufficient for employment, public reasonableness and civic competences or attachments that facilitate political participation. In sum, then, the state is generally recognised as the guarantor of last resort in arranging the liberties of co-equal citizens, and specifically in seeing to it that children receive an education that is sufficient for selfdetermination. Yet while there is basic consensus on the legitimate uses of liberty, and moreover concerning the various ways that the state may use its authority to regulate the uses of that liberty, the state's role continues to be controversial in its infringement of liberty in two areas: (1) its distribution of resources through coercive taxation, and (2) its encroachment on the prerogatives of parents in directing the lives of their own children. In what follows we limit our attention to the second item.

State-provided education, in all of its forms, has enjoyed a place of prominence for well over a century in all liberal democratic countries, and today support for public education remains strong. One of the guiding principles of state-provided education is that everyone, irrespective of income/wealth, religious or non-religious affiliation, race or gender, ability or disability, has access to a free education and, at least in principle if not in practice, the opportunity to make social advances as a direct result of that educational benefit. ${ }^{1}$ Above all, the availability of state-provided education to all children irrespective of income and wealth is viewed as a public good worth defending, even by those who opt out of the system. Though other relevant purposes and benefits of education may be named, it is sufficient to posit here that one of the principal purposes of public 
education is to enhance the child's wellbeing; stronger variations will include developing one's capacity to identify with and reflect upon a set of judgments and beliefs about what constitute a good life. Call this the autonomy argument. Yet public education is also frequently portrayed as a unique institutional vehicle through which fellow citizens from diverse backgrounds may be bonded together around a shared set of values. Call this the citizenship argument. Private forms of education, but also homeschooling, are thus seen as a serious threat to democratic solidarity and social cohesion. (We return to these arguments later.)

Be that as it may, pluralism of educational choice is already the norm in all liberal democracies, even though the scope and effects of pluralism will vary widely from place to place (see Glenn and de Groof, 2002). ${ }^{2}$ In most democratic societies schools that meet basic state requirements ${ }^{3}$ are generally free to develop a school curriculum consistent with pedagogical or religious philosophies and frameworks, and to recruit teachers qualified and eager to foster the sorts of outcomes adumbrated by those pedagogies. Assuming that parents who choose to home educate do so with the right sorts of motivations, viz., attending to both the academic and the personal needs of their children, there are still questions concerning whether parents are authorised and qualified to carry out their aims of home education. Additionally, there are worries that parents, acting upon their own sense of entitlement, will possibly infringe upon the interests of their children.

It should go without saying that parents' ready interest in the welfare of their children is not something that they would perceive as an infringement but rather an obligation or duty that derives from one simply being a parent. ${ }^{4}$ Framed as a feature of paternalism, parents consider it chiefly their responsibility to care for their own children, to nurture and to guide them, and this includes making most major decisions on their behalf. This is because children are, in the main, not accountable for their decisions in the same way as adults given their underdeveloped maturity and reasoning capacities (Archard, 2003; Merry, 2007a; Schapiro, 2003). How parental paternalism is expressed will vary widely, of course, but it will seem obvious to many parents that they are best placed to make decisions on behalf of their own children by virtue of their simply being the parent. Yet the paternalistic function of the state is also exercised on behalf of children, to ensure that their interests are looked after. Liberal democratic states normally have child-protection services and foster care because it cannot be assumed that parents will always look after their interests. So when it comes to education, both the parents and the state make claims on what is best for children.

One of the things being contested by parents who homeschool is not only the assumption that a child's autonomy and wellbeing is enhanced in schools, but also whether schools really do encourage worthwhile shared values and whether the offerings of citizenship are found exclusively within the domain of the school. Homeschooling parents also question whether those public benefits are the only-or even the most importantones worth pursuing. For example, the cultivation of family intimacy is 
generally recognised as an important good worth pursuing, both to parents and children (Brighouse and Swift, 2006; Merry and Howell, 2009), even though its public benefits remain unclear. While family intimacy may be a precursor to other forms of attachment and responsibility- a view advanced by Aristotle among others-the point here is simply that a ranking of personal or social goods may vary and this is consistent with robust pluralism. Personal goods may not always trump political goods such as civic unity or social cohesion, but neither do political goods automatically trump personal ones (see Galston, 2002, 2005).

Further, while the state may override parental authority in cases of abuse or neglect, parents normally possess the right to exercise their personal liberties both to meet a child's basic needs and also to pass along one's personal values. If parents do indeed have these prerogatives, it is not unreasonable to depict education both as a public, but also as a personal or private good. Naturally this will entail the prerogative to decide the sort of education one's child receives. In all liberal democracies these prerogatives are protected and revered rights and, consistent with these entitlements, parents may extend these prerogatives to homeschooling. Indeed, it is noteworthy that even its sharpest critics make no argument in favour of abolishing it.

Yet despite hard fought for freedoms to educate children at home, homeschooling continues to be viewed with suspicion. Alarmist reports in the United Kingdom, Germany and elsewhere document a fear that parents are inculcating beliefs, values or habits that run contrary to integration, national identity, and social cohesion (Spiegler, 2003; Stevens, 2005; Yuracko, 2008). Further, the aversion of some home educators to state oversight, coupled with rising concern over 'irresponsible' parenting, has precipitated appeals for the state to intervene to avert potentially harmful outcomes for children (Gaither, 2009; Holguin, 2003a, 2003b; Schneider, 2007; Unruh, 2007). To illustrate these concerns more concretely, we now consider the Dutch case in order to examine the phenomenon of homeschooling in a context that provides extensive (though restricted) parental freedoms within a robustly plural educational system.

\section{THE NETHERLANDS: PLURALISM, FREEDOM AND RESTRICTION}

In international discussions on the expansion of parental choice and the private delivery of education, the Dutch arrangement is frequently regarded as a unique setting for testing many arguments in the choice debate. The 'success' of the pluralist Dutch education system is advanced as an argument for more private delivery of education in other countries (Dennison, 1984) or, conversely, as a warning to not go down that road (Walford, 1995). Central to the Dutch arrangement are two constitutional rights: the right of freedom of education and the right of public and private institutions to equal public funding. As a result, approximately 70 percent of Dutch parents send their children to schools that, although established by private associations and managed by private school boards, are 
nonetheless fully funded and regulated by the central government (Dijkstra, Dronkers and Karsten, 2004).

At the end of the first decade of the 21st century, two trends stand out in the Dutch educational situation. The first is that within the Dutch school system the rights of parents count for less than the right of schools to realise their denominational or educational character. The liberty to provide education is chiefly the right to found a school and to teach on the basis of a particular philosophical conviction. ${ }^{5}$ Further, in the Netherlands private school boards now wield a lot of control over the organisation and direction of a school; yet one might also say that they operate as professional interest groups responsive to the demands of the local market and not, strictly speaking, to the specific concerns or interests of parents. Hence private school boards have become the agents of liberty rights.

Second, and perhaps more importantly, the traditional aversion to the state as sole educator is on the wane. While in the past the unity of the Netherlands had developed by focusing on the right to be different, prominent politicians and publicists now see this as its greatest threat. Changes within the Dutch political climate, due only partly to large pockets of urban poverty among visible immigrant minorities, have been dramatic in the past ten years and talk of 'shared cultural values' now has widespread currency. Thus, within this new 'framework' the liberty of parents with 'deviant' religious or pedagogical ideas, including the desire to homeschool one's children, does not seem to fit.

\section{Homeschooling in the Netherlands}

Notwithstanding the diversity of options within the Dutch educational system, the choices on offer do not address every parental concern. Accordingly, in 1969 the compulsory school attendance law (Leerplichtwet, art. 5,b) made provisions for parents to exempt children from school if the parents objected to the direction or orientation of the available schools. Reasons for exemption are limited to matters of conscience and not to teaching methods. So, for example, parents whose spiritual convictions are in conflict with the orientation of the local school are, in principle, permitted to request an exemption from compulsory school attendance.

Even so, the number of homeschooling families in the Netherlands remains extremely low. Fewer than two hundred and fifty Dutch children were homeschooled during the 2006-07 school year, or approximately $0.01 \%$ of the total number of school aged children (Blok, 2004; Blok and Karsten, 2008). Yet even these few families have managed to do so with great difficulty, and the former Minister of Education van der Hoeven openly declared that homeschooling was not in the interest of the child (Klagen over het Onderwijs 2004). Today, oversight of homeschooling is absent, and little is known about whether, or how, exempted children are being educated outside of school. 
In 2003, the government initiated a discussion about the position of home education in the Netherlands. The present government does not support extending the possibilities for home education; it explicitly hopes that homeschooling will only be an exception and not an alternative to the school system. Presently the Ministry of Education is calling for further research, detailing the experiences in other countries, in order to ascertain the extent to which homeschooled children manage to succeed both in higher education and the labour market. It is also considering the introduction of specific procedures for inspection of the education of children of parents who are exempted under the compulsory education law.

So while homeschooling has become an increasingly popular form of parental choice in North America and numbers of homeschooled children in other European countries have doubled or tripled in recent years, authorities in the Netherlands are reluctant, if not fiercely opposed, to the expansion of homeschooling. Indeed, what remains clear in the Dutch case is that despite the constitutional guarantee of freedom of education, the liberty to homeschool in the Netherlands remains highly suspect, if not strongly discouraged. Parental liberty, then, is generally restricted to the existing system.

Of course one reason why the Dutch are generally nonplussed by the decision to homeschool derives from the fact that its school system is purposefully plural in character. It therefore seems unnecessary to opt out of a system in which so many choices are available. Yet this is a thin argument, for there is a host of reasons why parents may decide to homeschool that have nothing to do with school diversity. ${ }^{6}$

There is a related explanation, which points to a time-honoured tradition of freedom of religion in a country historically torn along denominational lines. This way of organising and viewing educational liberty has cast a long shadow over the debate concerning permissible and impermissible forms of education. This history partly explains the worries about further fragmentation along - chiefly non-Christian-religious lines. Here the problem with homeschooling seems to be that it steps outside of wellrecognised boundaries and thus represents an unknown commodity whose time to be fairly considered has come. Thus homeschooling raises eyebrows - in the Netherlands, but also elsewhere-because there is very little knowledge, outside of homeschooling circles themselves, of what goes on. This concern is not trivial, but without compelling evidence to suggest that homeschooling harms children, or fails to prepare them for meaningful participation in society, this objection loses much of its force.

\section{HOMESCHOOLING AND OBJECTIONS TO PARENTAL CHOICE}

The brief foregoing discussion illustrates that even in highly pluralistic school systems, such as the Netherlands, where multiple educational philosophies and denominational differences are supported by the state, 
attitudes towards homeschooling continue to be negative and formidable obstacles remain in place. Much strong resistance arises from the belief that compulsory attendance laws safeguard children's interests by ensuring an adequate level of education necessary for functioning in society and contributing to its economic stability. And certainly an educated person is more free-to reflect, to take up pursuits that require more refined skill sets, to enjoy higher levels of control over one's work, etc. - than one who is not.

Yet these beliefs are not in conflict with the view that education routinely occurs outside of schools. Indeed, homeschoolers frequently remind their critics that schooling and education are not the same; there are many sites of education that facilitate learning, discovery and growth, including libraries, sites of business and the outdoors. It seems fairly uncontroversial, then, to posit that schools are not the exclusive sites of educational experience.

Let us now turn to what we earlier called the citizenship argument and the autonomy argument and focus on those more carefully. The citizenship argument, among other things, implies that the expansion of homeschooling would undercut the conditions for a stable and just democratic society. We will parse this claim into two more specific objections: first, homeschooling conforms to a privatisation impulse that will exacerbate social inequality; and second, homeschooling facilitates unmonitored private allegiances - such as religious commitment-that will inevitably aggravate societal conflict. We then turn to the autonomy argument, whose main concern is with the wellbeing and (future) liberty of the child. In both cases we draw upon the Dutch situation for examples.

\section{Privatisation and Social Inequality}

There are many ways to interpret inequality. We will not examine those here. For this discussion, social inequality refers to educational opportunities that are available to some and not to others, thus advantaging a fortunate few. In the educational realm, this often takes the form of the familiar public-private debate. Yet the public-private school distinction in the Netherlands, while not meaningless, certainly does not represent the sharp division that it generally does in many other countries. ${ }^{7}$ In theory, the system is designed to be open and accessible to all potential choosers, provided there is sufficient space for the applicant. So in the Netherlands 'private' options are already available within the state-funded system of education. Private schools, within a properly regulated system, can thus operate as a public resource (Merry, 2007b).

So how well does the social inequality objection fit the decision to homeschool? As we have seen, homeschoolers feel that the choices available to them do not address all of their concerns. They would also argue that it is at least controversial to claim that children's interests are better served in the public sector. As we will argue below, the interests of children are a complex affair and must be assessed according to specific 
contexts and individual characteristics. In many cases, children are certainly better served in private settings if this means fewer incidents of bullying, less exposure to risk-taking behaviour, and more attention is given to the learning needs of a particular child (Merry and Howell, 2009).

But does homeschooling contribute to social inequality? Here the concern seems to be that children in advantaged families will receive a uniquely beneficial education to which others do not have access. After all, homeschooling normally requires that certain arrangements and resources be available in order for things to go well. Homeschoolers generally consist of two-parent families (Ray, 2005); the typical homeschooling parent has a university degree (ibid.); ${ }^{8}$ most have (or make) the time to educate their children at home; most are very motivated, etc. Indeed, without these-and other-conditions there is a strong disincentive to take up or sustain the enterprise.

There are two possible responses to this. First, these characteristics are shared by many parents whose children attend schools, and one might just as easily argue that having extra parental resources, in addition to what schools are able to offer-attentive teachers, lab equipment, class variety, favourable peer effects, extracurricular activities-advantages children who attend schools. To be sure, homeschooled children may receive more individualised attention, and, if things go well, spend more time with their parents. But strictly speaking this may or may not be an advantage, and it is far from obvious how this exacerbates social inequality. More likely, these are hypothetical allegations of benefits and outcomes for which there is simply a paucity of evidence.

Second, the concern that children who are homeschooled will receive extra attention, care and nurture, ironically implies that the worry about protecting children's interests may be misplaced. Yet even if these concerns are not misplaced, there is no reason to assume that homeschooling, with the right regulatory conditions in place, couldn't work alongside existing educational systems. ${ }^{9}$ But the point here is simply that pluralism and social equality need not be incompatible aims; private impulses can be tamed by sensible-and not heavy-handed-state regulation whose goal it is to ensure that basic fairness procedures apply and that children's interests are also served.

\section{Private Interests and Societal Conflict}

The second objection, that pursuing private interests will exacerbate societal conflict, addresses the tension between individual liberties and broader societal welfare sustained through mutually shared civic obligations and shared values. In all societies the concern for social cohesion appears to centre on citizenship as a set of necessary dispositions for binding persons of disparate backgrounds together around a constellation of shared interests and commitments. Citizenship will entail different kinds of responsibilities and obligations. Weaker variants require knowledge about the way the political system works, and also 
that one obey the existing laws and respect the constitutional freedoms of others, even when one does not personally agree with their choices. Stronger variants entail cultivating a set of dispositions capable of sustaining political practices that require that citizens promote the effective functioning of their own political institutions, and perhaps the most obvious way it does this is through schools. Yet whichever version one prefers, citizenship represents only one of the interests or commitments that persons have. Moreover, there is no reason to think that one's public duties ought to take priority over all other interests. Indeed, it would be difficult to imagine this being true for anyone but the most zealous patriot.

Promoting good citizenship (which incidentally is now compulsory in all Dutch schools since 2006) is predicated on the idea that schools are the best place to promote social interaction on the basis of equality and respect. Some parents may want to foster that same type of interaction, but some may not. It may be the case that some parents whose loyalties lie elsewhere will nourish commitments that (appear to) militate against the public good. The state will want to ensure that what is a positive alternative for some is not used by others as a vehicle to promote intolerance.

Here two things should be noted. First, the claim that shared school attendance fosters greater social cohesion has never been convincingly demonstrated, notwithstanding repeated claims to the contrary. ${ }^{10}$ Second, social cohesion must be balanced against the demands of pluralism: liberal democratic states must struggle to balance shared interests and responsibilities with the equally important aim of facilitating the liberties of its citizens to pursue life projects that enhance their personal wellbeing. So pluralism (as a political value) requires that persons can do permissible-though perhaps not always desirable-things with their liberty. This means respecting the other's right to make one's own choices and live with the consequences.

\section{The Interests of Children}

The third and final objection to homeschooling we consider is that it interferes with the wellbeing and (future) liberty of children. Here we turn and look more squarely at the autonomy argument. The claim goes something like this: parents who homeschool their children exercise complete authority over their education; such absolute control limits the child's exposure to different ways of life. We therefore have reason to worry about the homeschooled child developing the capacity to become a free, self-determining agent. 'To become free,' Reich writes, 'students must be exposed to the vibrant diversity of a democratic society so that they possess the liberty to live a life of their own design' (Reich, 2002, p. 59). The restriction of parental liberty is therefore necessary in order to prevent children's liberties from being stunted, or their interests from being neglected. 
What precisely are the interests of children? The interests of children will diverge, in the details, from one child to the next, which is to say that beyond rudimentary welfare concerns the 'needs of children' cannot be generalised but will require attention to specific cases. Yet in the main we may say that children, like all human persons, have an interest in wellbeing. Though broad in scope, wellbeing will minimally entail basic protections, nourishment, and education. But wellbeing will equally entail the capacity to take up pursuits (e.g. vocations and relationships) that will contribute to a flourishing life. Put more strongly still, wellbeing is related to the (future) interest in self-governance, viz., the capacity to direct one's own life and to identify with it from the inside. One's capacity to think and speak for oneself is a valuable good whose future realisation requires the right sorts of social arrangements and personal care. The challenge lies in determining just which sorts of environments or personal attention fit that prerequisite, not least of which because the scope of any child's needs is naturally a complex affair and at least partly will be determined by personal characteristics as well as contextual constraints. Therefore, when we examine the educational interests of children, a one-size-fits-all approach is not only impractical and unpopular, it is also likely to be unjust.

To avert unnecessary harms, liberal critics of homeschooling typically focus on its lack of public accountability. Oversight of some kind is believed necessary to curtail privatisation tendencies that threaten social cohesion and equality of opportunity, but also an erosion of good citizenship and public reasonableness. That, in a nutshell, was the citizenship argument we addressed above. But the more pressing liberal concern boils down to a loss of individual autonomy. Again, Reich, writes of homeschooling: 'total customization ... threatens to insulate students from exposure to diverse ideas and people and thereby to shield them from the vibrancy of a pluralistic democracy' (p. 56). Consequently, strict guidelines and oversight are believed necessary for controlling parental liberties in order to protect the interests of children.

There are a number of problems with this line of reasoning. First, it is curious that homeschoolers would be singled out here. Parents of all sorts 'customise' the education and upbringing of their children in a million different ways, especially when they are more educated and have plentiful resources at their disposal. These include a range of educational and recreational environments in which parents surround themselves and their children with those who share the same core values, habits and preferences. ${ }^{11}$ Unsurprisingly there is little concern with this sort of customisation.

Second, liberal critics typically presume more than they prove and not infrequently cast hypothetical allegations of aims and outcomes for homeschoolers (or private schoolers) against idealised aims and outcomes of public schools (Hardenburgh, 2005; Howell, 2003; Merry, 2007b). That is, public schools are cast as uniquely qualified to facilitate meaningful liberal virtues of civic intelligence and engagement. Yet not only is the basic claim highly questionable, especially for all sorts of marginalised 
groups, it also of course ignores the fact that public schools promote (explicitly and through the hidden curriculum) all sorts of values both at odds with parents' wishes as well as conditions favourable to the cultivation of autonomy (De Ruyter and Merry, 2009; Molnar, 2005; Pope, 2001; Powell et al., 1985).

Third, putting aside for the moment the daunting logistical challenges associated with homeschool regulation, one is confronted with the immense difficulty of assessing for liberal virtues (among them 'civic preparedness', public reasonableness, multicultural tolerance and autonomy) in an uncontroversial way. Robert Kunzman sensibly observes:

What does it mean for us to be able to 'step back' and reflect on what we've been taught about the good life, to evaluate and perhaps change those beliefs? And even if we could reach a consensus about such criteria, it seems beyond the pale to assert that state departments of education are qualified or capable of making such judgments concerning the thousands of homeschooled children within their borders (Kunzman, 2009, p. 325).

But let us assume for a moment that strict state oversight of all educational options is the norm. Even so, the prerogatives of parents to choose an education they deem suitable for their child will continue to be widely recognised and protected by constitutional law and international declarations on human rights. Increasingly prohibitions against home education are being struck down as unconstitutional, arbitrary and discriminatory. These are simply the political realities. While parents may not exercise their liberties without restraint, they are generally assumed to be best placed to know and understand what is best for their own children. Even the fiercest critics of home education understand on principled grounds that parents enjoy important prerogatives where their children's education is concerned, but also that a robust pluralism must allow for a wide range of choices in the educational sphere.

Here, then, is the crux of the matter: the liberty of parents to select an education they deem suitable for their own children, provided that parents' own liberties do not unduly or improperly infringe upon the liberty of their children-which in any case is rather difficult to assess - is one that is consistent with a liberal democratic state aiming to facilitate a plurality of choices as well as the exercise of individual liberty. Where liberty is restricted by the state, it must be justified either by considering the general harms done to others, or by attending to the specifics of individual cases. Parental prerogatives are not absolute, but parents assume an important role in the allocation of authority over the education of their children, and, as we have argued, parents generally are better placed than the state to know what their children need.

Either side can err. States can overextend their legitimate reach by being too intrusive into the lives of families, disrupting important forms 
of intimacy and attachment; states also can wrongly assume that civic virtues are exclusively fostered within the domain of their own institutions. Parents, in turn, can abuse their liberty by misapplying it to their children, equating their own wellbeing with their children, and hindering the child's development by imposing expectations and beliefs with which a child may not easily identify. Parents may also thwart the development of their child's liberty by sending them to the nearest state school, where they may be under-challenged, or worse, continually bullied and harassed. So while parents may in fact be best placed to know what is best for their own children, their paternalistic wisdom is far from infallible.

So a balance is needed. In the first section, we demonstrated that states do not grant unlimited freedoms; coercive restrictions of liberty by the state are justified when doing so ensures the expression of liberty for others. Indeed, liberty is not an all-consuming value, overriding all others. The restriction of liberty also extends to persons as parents. The liberties of parents need to be balanced not only against the interests of other parents (parents may not hoard resources that effectively deny opportunities to other parents and their children), but also against their own children.

This means that the preferences, interests and liberties of their children also must be considered. Hence the liberty rights of parents with respect to their own children are not absolute, and the state interference with parents' liberty can go some distance in promoting a child's wellbeing. The point here is simply that a system of checks and balances will help to insure against liberty being abused but that the details of that system ${ }^{12}$ remain somewhat elusive beyond specific cases. To help avert the abuse of liberty, the distribution of authority - with neither parents nor the state controlling all of it-constitutes wise policy.

\section{CONCLUSIONS}

In this article we have examined the tensions that arise in the case of homeschooling when the liberty rights of parents potentially clash with the interests of children and the expectations of the state. With respect to the basic liberties of parents to choose an education they deem suitable for their child, homeschooling will increasingly be an attractive option to parents who find the alternatives available to them unsatisfactory. Accordingly, liberal democratic states will play a crucial role in facilitating the choices parents have, and those choices must be consistent with serving the interests of the child. Yet beyond basic welfare concerns the interests of children, as we have shown, will not conform to one model or approach, but need to be appraised in particular cases.

If the liberties of children are disregarded or thwarted through homeschooling or any other means, the state's role as protector of children's interests will trump that of the parents. That is, the best grounds 
for restricting the liberty rights of parents to homeschool would be to avert the infringement of a child's wellbeing, thus inhibiting its (future) liberty and capacity for self-governance. However, homeschooling does not per definition constitute such an infringement, and thus all cases must be decided on the basis of evidence-which entails some form of oversightand not conjectures about hypothetical privatising effects that threaten to eat away at social cohesion, good citizenship or autonomy. The decision to homeschool appears consistent with any meaningful interpretation of the liberty to follow one's conscience. Unless there is clear evidence of a child's wellbeing being contravened, the restriction of legitimate liberty to choose among a range of reasonable educational options constitutes an injustice.

Homeschooling need not occur-as it does in many places-completely out from under the governance of the state. Given what we have argued concerning the role that states may play in ensuring that children are looked after, its paternalistic role must not be discounted. We briefly considered the Netherlands as a test case for homeschooling and it seems appropriate to return to it here. The Dutch model exemplifies a facilitative state that values and supports both educational pluralism and parental liberty. Public and private options are incorporated into the Dutch educational system so that privatising impulses are reasonably tamed. Yet the flexibility of the Dutch system is deceptively thin. The urge to regulate and control what all schools do produces effects that even the system's internal diversity cannot dispel. While the Netherlands does a better job than most in balancing parental liberty, children's interests and state oversight, our examination of the homeschooling case exposes at least one worrying inconsistency. However, given its relatively small size, the Netherlands may be able to experiment with more ambitious forms of oversight (e.g. periodic home inspections) that are not taxing either to the government or too intrusive to the families concerned. Importantly, recent evidence suggests that Dutch homeschooling families are not averse to such oversight, provided that supervision is not punitive in character (Blok and Karsten, 2008).

But for that to happen, much would need to change. While not technically illegal, homeschoolers in the Netherlands face daunting bureaucratic obstacles and populist pressures to restrict-with talk of social cohesion and integration-educational choice. What is particularly striking is that the constitutional guarantees of parental liberty with respect to freedom of education appear to be somewhat arbitrarily circumscribed.

By treating homeschooling as aberrant the Netherlands also risks illegitimately restricting parental liberty and misapplying its own constitutional principles of freedom of education to include only institutionalised schools. Doing so, we suggest, will inevitably lead to conflict. If the Netherlands manages to resist these impulses, it will demonstrate that it continues to be a country where liberty-with appropriate restrictions-continues to be a value worth protecting and a country where the wellbeing of children continues to be a top priority. 


\section{Correspondence: Michael Merry, Faculty of Social and Behavioral Sciences, University of Amsterdam, Nieuwe Prinsengracht 130, 1018 VZ Amsterdam, The Netherlands. Email: M.S.Merry@uva.nl}

\section{NOTES}

1. For the purposes of our argument we ignore here the economic rationale for public education, as well as the obvious effects of social and cultural capital, but also individual talent and effort, that structure and mediate institutional opportunities such as schools.

2. For example, private education in one context may exacerbate social inequality while enhancing it in another. Its effects will depend on a number of institutional features and demographical variables.

3. These will include provisions for health and safety, teacher qualifications, curricular aims that conform to state-mandated learning targets/standards, etc.

4. While certainly not true all of the time or for everyone, for perhaps a majority of parents the affection one has for her own child eclipses from view the conviction that one acts from a sense of duty. Rather, one generally is motivated by love, even when one's judgments are deeply fallible and often are not construed by the child as loving at the time they occur.

5. School types fully funded by the state now include Steiner, Dalton, Jenaplan, Montessori, Iederwijs, Hindu, Catholic, Islamic, Jewish and a variety of Protestant schools.

6. For example, parents may wish to adapt teaching methods to fit the child's learning style, foster intimacy with their child, or supplement their education with religious belief (see Collum, 2005; Duvall, 2005; Isenburg, 2007; Merry and Howell 2009; Rothermel, 2003; Winstanley, 2009).

7. Despite this arrangement, there is growing evidence in the Netherlands that some private schools do contribute to social inequality inasmuch as they specifically cater to cultural or pedagogical interests of middle-class parents. Many schools impose 'voluntary fees' for all sorts of extracurricular activities, and poorer parents, not realising these fees are voluntary, steer away from those schools. However, except for a tiny number of elite international schools, which generally cater to expatriates, private tuition-based education is illegal (see Weenink, 2005).

8. For example, the education level of Dutch parents who homeschool is well above the national average, with $65 \%$ of mothers and $59 \%$ of fathers having received post-secondary education. See Blok and Karsten, 2008.

9. The main challenges of course are logistical. The Dutch Ministry of Education presently questions whether the costs and administrative burdens are feasible, particularly if the number of homeschoolers were to grow (Blok and Karsten, 2008). While oversight in some countries does not exist, the Netherlands could look to Belgium, Austria, Ireland or France for innovative approaches. (See Sperling, 2005).

10. Indeed, while it may be possible to speak of shared political and cultural values, the historically diverse Dutch system of education has facilitated a range of divergent educational visions, It remains to be seen whether the recent citizenship mandates will assist in furthering the aims of social cohesion (see Merry and Milligan, 2009).

11. The difference 'exposure to diverse ideas and people' is supposed to make is, we suspect, little more than a quaint idea far removed from the actual experience of most children who attend schools. Particularly given the manner in which secondary students self-select (or have parents select for them) classes, extracurricular activities and friends, the homeschooled child who primarily socialises with other homeschooled children is not an exceptional case. In Europe the tracking systems are even more likely to limit interaction of students from different social backgrounds.

12. With respect to religious schools, I have defined oversight as 'a system of accountability that would equitably allocate the funds and governance for staffing and maintaining the general mechanisms necessary for safety, quality of learning, and self-reliance' (Merry, 2007b, p. 260). Given the huge variability in homeschooling environments, oversight will require a more cautious approach. Oversight of homeschooling requiring, for instance, registration and periodic testing may be appropriate but in the absence of compelling reasons for more intrusive kinds of oversight the state risks losing its legitimacy in the eyes of parents. David Archard also reminds 
us of the class-based risks associated with oversight that almost certainly will penalise lower income families and minority groups (Archard, 1993, pp. 114-15). The likelihood that oversight will thus reinforce existing inequalities is something proponents of oversight often neglect.

\section{REFERENCES}

Archard, D. (1993) Children: Rights and Childhood (London, Routledge).

Archard, D. (2003) Children, Family and the State (Hampshire, Ashgate).

Blok, H. (2004) Performance in Home Schooling: An Argument Against Compulsory Schooling in the Netherlands, International Review of Education, 50, pp. 39-52.

Blok, H. and Karsten, S. (2008) Vervangend onderwijs aan kinderen van ouders met een richtingbezwaar [Substitutional Education of Children of Parents with Objections] (Amsterdam, Kohnstamm Instituut).

Brighouse, H. and Swift, A. (2006) Parents' Rights and the Value of the Family, Ethics, 117, pp. 80-108.

Collum, E. (2005) The Ins and Outs of Parental Motivations and Student Achievement, Education and Urban Society, 37.3, pp. 307-35.

Dennison, S. (1984) Choice in Education (London, Institute of Economic Affairs).

De Ruyter, D. and Merry, M. (2009) Why Education in Public Schools Should Include Religious Ideals, Studies in Philosophy and Education, 28.4, pp. 295-311.

Dijkstra, A., Dronkers, J. and Karsten, S. (2004) Private Schools as Public Provision for Education: School Choice and market Forces in the Netherlands, in: P. J. Wolf and S. Macedo (eds) Educating Citizens. International Perspectives on Civic Values and School Choice (Washington DC, Brookings Institute Press), pp. 67-90.

Duvall, S. (2005) The Effectiveness of Homeschooling Students with Special Needs, in: B. Cooper (ed.) Homeschooling in Full View: A Reader (Greenwich, Information Age Publishing), pp. 151-66.

Galston, W. (2002) Liberal Pluralism: The Implications of Value Pluralism for Political Theory (Cambridge, Cambridge University Press).

Galston, W. (2005) The Practice of Liberal Pluralism, (Cambridge, Cambridge University Press).

Gaither, M. (2009) Homeschooling in the USA: Past, Present and Future, Theory and Research in Education, 7.3, pp. 331-346.

Glenn, C. and De Groof, J. (2002) Finding the Right Balance: Freedom, Autonomy and Accountability In Education (West Lafayette, IN, Purdue University Press).

Hardenburgh, N. (2005) Through the Lens of Homeschooling, in: B. Cooper (ed.) Homeschooling in Full View (Greenwich, Information Age Publishing), pp. 97-108.

Holguin, J. (2003a) A Dark Side to Homeschooling, available at: http://www.cbsnews.com/stories/ 2003/10/13/eveningnews/main577817.shtml

Holguin, J. (2003b) Homeschooling Nightmares, available at: http://www.cbsnews.com/stories/ 2003/10/14/eveningnews/main578007.shtml

Howell, C. (2003) Justice, Inequality and Home Schooling, Home School Researcher, 15.3, pp. $1-9$.

Isenburg, E. (2007) What Have We Learned About Homeschooling?, Peabody Journal of Education, 82, pp. 387-409.

Klagen over het Onderwijs [Complaints about Education] (2004) Algemeen Dagblad, 3 July.

Kunzman, R. (2009) Understanding Homeschooling: A Better Approach to Regulation, Theory and Research in Education, 7.3, pp. 311-330.

Nozick, R. (1974) Anarchy, State and Utopia (New York, Basic Books).

Merry, M. (2007a) The Well-being of Children, the Limits of Paternalism, and the State: Can Disparate Interests Be Reconciled?, Ethics and Education, 2.1, pp. 39-59.

Merry, M. (2007b) Should the State Fund Religious Schools?, Journal of Applied Philosophy, 24.3, pp. 255-270.

Merry, M. and Howell, C. (2009) Can Intimacy Justify Home Education?, Theory and Research in Education, 7.3, pp. 1-19.

Merry, M. and Milligan, J. (2009) Complexities of Belonging in Democratic and Democratizing Societies, Journal of Muslim Minority Affairs, 29.3, pp. 313-325. 


\section{M. Merry and S. Karsten}

Molnar, A. (2005) School Commercialism: from democratic ideal to market commodity (New York, Routledge).

Pope, D. C. (2001) Doing School: How We Are Creating a Generation of Stressed Out, Materialistic and Miseducated Students (New Haven, CT, Yale University Press).

Powell, A., Farrar, E. and Cohen, D. (1985) The Shopping Mall High School: Winners and Losers in the Educational Marketplace (Boston, MA, Houghton Mifflin).

Ray, B. (2005) A Homeschool Research Story, in: B. Cooper (ed.) Homeschooling in Full View: A Reader (Greenwich, Information Age Publishing), pp. 1-19.

Reich, R. (2002) The Civic Perils of Homeschooling, Educational Leadership, April, pp. 56-59.

Rothermel, P. (2003) Can We Classify Motives for Home Education?, Evaluation and Research in Education, 17.2\&3, pp. 74-89.

Schapiro, T. (2003) Childhood and Personhood, Arizona Law Review, 45.3, pp. 575-594.

Schneider, J. (2007) Lack of Oversight for Home-schooled Alarms Educator, Lansing State Journal 27, October.

Somerville, S. (2005) Legal Rights for Homeschool Families, in B. Cooper (ed.) Homeschooling in Full View (Greenwich, Information Age), pp. 135-149.

Sperling, J. (2005) Thuisonderwijs in Nederland: een buitenbeentje in Europa [Homeschooling in the Netherlands; A Misfit in Europe], School en Wet (April), pp. 9-12.

Spiegler, T. (2003) Home Education in Germany: An Overview of the Contemporary Situation, Evaluation and Research in Education, 17.2\&3, pp. 179-190.

Stevens, M. (2005) The Normalisation of Homeschooling in the USA, Evaluation and Research in Education, 18, pp. 90-100.

Unruh, B. (2007) Judge Warns of Child-Abusing Homeschoolers. Available at: http:// www.wnd.com/news/article.asp?ARTICLE_ID=54624

Walford, G. (ed.) (1995) School Choice and the Quasi-market (Oxford, Symposium Books).

Weenink, D. (2005) Upper Middle-class Resources of Power in the Education Arena. Dutch Elite Schools in an Age of Globalization. Unpublished PhD thesis, University of Amsterdam.

Winstanley, C. (2009) Too Cool for School? Gifted Children and Homeschooling, Theory and Research in Education, 7.3, pp. 347-362.

Yuracko, K. (2008) Education Off the Grid: Constitutional Constraints on Homeschooling, California Law Review, 96, pp. 123-184. 